\title{
The influence of gestational age at term on breastfeeding: a cohort study*
}

Influência da idade gestacional no termo sobre o aleitamento materno: estudo de coorte Influencia de la edad gestacional a término en la lactancia materna: un estudio de cohorte

How to cite this article:

Michelin NS, Nunes HRC, Carvalhaes MABL, Parada CMGL. The influence of gestational age at term on breastfeeding: a cohort study. Rev Esc Enferm USP. 2021;55;e20200381. doi: https://doi.org/10.1590/1980-220X-REEUSP-2020-0381.

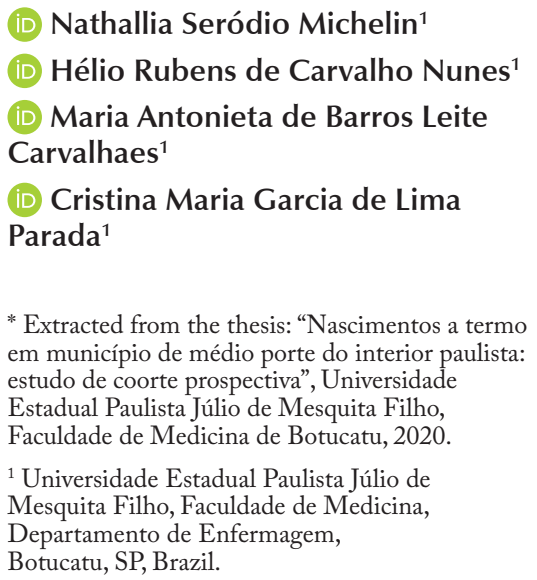

Departamento de Enfermagem,

\begin{abstract}
Objective: To identify the effect of the category gestational age at term on breastfeeding in he first hour of life, the duration of exclusive breastfeeding, and practice of breastfeeding twelve months from birth. Method: Single cohort, with a one-year prospective followup of 541 children. A hierarchical analysis was performed, with models adjusted per Cox regression, considering critical $\mathrm{p}<0.05$. Results: During raw analysis there was a statistical difference on breastfeeding in the first hour of life $(\mathrm{RR}=1.54$; CI95\%= $1.12-2.12 ; \mathrm{p}=0.008)$. However, in the final analysis, there was no association between gestational age at term and breastfeeding in the first hour of life, duration of exclusive breastfeeding, and the practice of breastfeeding twelve months from birth. Secondarily, higher age and education, cesarean section, birth at private services, and the need for resuscitation were observed to have a negative influence. Duration of previous pregnancy favored breastfeeding in the first hour of life. Using baby bottle and pacifier was negative for breastfeeding in the first year of life. Conclusion: There was no association between the category gestational age at term and breastfeeding. The association of outcomes pointed out by the scientific literature have been confirmed.
\end{abstract}

\section{DESCRIPTORS}

Term Birth; Gestational Age; Breast Feeding; Feeding Behavior; Maternal-Child Nursing. 


\section{INTRODUCTION}

According to the World Health Organization (WHO), the survival of newborns and child development are closely related to breastfeeding. This is recommended to be encouraged for all mothers in the first hour from birth, as is exclusive breastfeeding (EBF) for six months from birth and breastfeeding $(\mathrm{BF})$ with complementary nutrition for the first two years of life or longer ${ }^{(1)}$.

This recommendation is supported by evidence of the benefits of exclusive breastfeeding in comparison with any other form of feeding infants ${ }^{(2)}$. Despite the relevance of this practice, in low- and medium-income countries, only $37 \%$ of children younger than six months are exclusively breastfed and, with few exceptions, the duration of breastfeeding is even lower in high income countries ${ }^{(3)}$.

Breastfeeding in the first hour of life is determinant for the success of breastfeeding, since it contributes to the development of children's sense of smell, which is essential for the newborn to properly seek the breast ${ }^{(4)}$. The factors associated to breastfeeding in the first hour of life include newborn weight, delivery route ${ }^{(5)}$, gestational age, and complications during birth and the immediate post-partum period. The maintenance of $\mathrm{EBF}$ in the first six months and the practice of $\mathrm{BF}$ in the first two years of life are intimately related to age ${ }^{(5)}$, education ${ }^{(6)}$ and maternal skin/ethnicity ${ }^{(7)}$, marital status ${ }^{(8)}$ and socioeconomic condition ${ }^{(6)}$, number of prenatal consultations and type of delivery ${ }^{(5)}$ and child-related factors, such as sex ${ }^{(9)}$, appropriate weight for gestational age ${ }^{(5)}$, early skin-to-skin contact $^{(5-6)}$, vitality at birth ${ }^{(5)}$, and use of pacifier ${ }^{(9)}$.

Few studies approach how breastfeeding is influenced by the subcategories which constitute pregnancy term: early term $\left(37-38^{6 / 7}\right.$ weeks), full term (39-40 $40^{6 / 7}$ weeks), and late term $\left(41-41^{6 / 7} \text { weeks }\right)^{(10)}$. This classification was proposed based on studies which suggested worse neonatal results for babies born at early term when compared to full and late term, especially regarding the aggravation of respiratory conditions at birth ${ }^{(11)}$ and the increase of neonatal mortality ${ }^{(12-13)}$. Thus, early term birth may have a negative repercussion on the onset and duration of BF.

Two studies approached the relation between gestational age at term and breastfeeding: one described that each additional gestational week at birth would increase the chances of the infant being breastfed by $8 \%(\mathrm{OR}=1.08$; $95 \% \mathrm{CI}=1.07-1.16)^{(14)}$, whereas the other concluded that, in the absence of complications, there was no association between being born at early term and EBF duration (38.2\% vs. 35.7\%; $p=0.22)^{(15)}$. Considering these divergent results, this study has the objective of identifying the effect of the category gestational age at term on breastfeeding in the first hour of life, the duration of $\mathrm{EBF}$, and the practice of $\mathrm{BF}$ twelve months from birth.

\section{METHOD}

\section{Study Design}

This is a cohort study, part of the study Cohort of Botucatu Infants (CLaB - Coorte de Lactentes de Botucatu), which has followed mothers and their newborns from their first month to their first year of life.

\section{Population}

The population comprised mother-baby pairs living in Botucatu, São Paulo, Brazil. All dyads which had been to a medical or nursing consultation in a neonatal screening primary care unit from July 2015 to February 2016 were invited to participate. This has totaled 650 mothers and 656 babies. Excluding premature and stillborn children and twins, there was a total of 608 dyads. During their first year of life, there were 67 refusals or losses to follow-up (9.9\%) and comparing this group to the one which concluded their participation in the cohort, with 541 dyads, there were no significant differences between sociodemographic characteristics and maternal health conditions.

\section{Data Collection}

The invitation for study participation took place in a neonatal primary care unit. The objectives and procedures of this research were explained and, in case of agreement, the Informed Consent Form was signed. This unit provides care to children born at the two maternities of Botucatu, one public and the other private, with a high coverage of over $90 \%$ of births in this municipality. Follow-up was terminated in February 2017.

Data collection was performed by a trained and remunerated team in seven moments during the first year of the children's' life: in person in the first, third, sixth, ninth, and twelfth month and over the telephone on the second and fourth months of the children's lives. To verify the integrity of the interviews, the field supervisor has selected a random sample of $5 \%$ of the dyads and performed a new interview over the phone, so as to verify possible inconsistencies and, when necessary, the database was corrected.

During cohort inclusion, mother and newborn identification data were collected; these data were sociodemographic and related to previous and current gestational record, delivery, and birth. During the other in-person interviews, performed at home, and telephone interviews, the infants' nutritional status, their health conditions, and use of pacifier and/or baby bottle were investigated. The data collection instruments were elaborated specifically for this study.

\section{Data Treatment and Analysis}

Gestational age (independent variable) was treated in a categorical manner: early term, full term, and late term, which was obtained through early ultrasound (up to 14 weeks) or, in its absence, estimated based on the date of the last menstruation, if the mother reported being sure of this date.

The analyzed outcomes were breastfeeding in the first hour of life (yes, no), duration of EBF (days), and BF at 12 months (yes, no).

The association between term and numeric variables was analyzed through Kruskal-Wallis non-parametric tests, followed by Mann-Whitney test for multiple comparisons 
(among the three term categories) and the association between the term categories and categoric variables was analyzed with the Chi-squared test or Fisher's Exact test.

The analysis of association between gestational age and each outcome was estimated through Cox multiple regression, based on a hypothetic model of inter-relation among variables, organized into four blocks, according to its precedence in the determination of each outcome. In the specific case of binary outcomes (breastfeeding in the first hour of life and breastfeeding 12 months from birth), equal times were assigned to all units of analysis, incorporating this information into the process of analysis ${ }^{(16)}$. The final model proposed for each outcome has discriminated hierarchically superior risk factors as exerting their action over those in the lower levels (Figure 1).

Based on block 1, the multiple regression model containing all variables of this block $(\mathrm{mb1})$ and no other was adjusted. The multiple regression model was then adjusted; it contained all the variables of block $2(\mathrm{mb} 2)$ and no other. Subsequently, the multiple regression model containing the variables of block 2 which had $\mathrm{p}<0.20$ in $m b 2$ plus variables presenting $\mathrm{p}<0.20$ in $m b 1$ was adjusted; this process was called adjustment per superior block, and block 1 was superior to block 2. After this, the multiple regression model with all variables of block $3(\mathrm{mb} 3)$ and no other was adjusted and the multiple regression model with variables presenting $\mathrm{p}<0.20$ in $m b 1, m b 2$, and $m b 3$ was then adjusted, which led to another adjustment per superior blocks, in which blocks 1 and 2 were superior to block 3 . A model with all variables in block $4(\mathrm{mb} 4)$ and no other was then adjusted and, finally, a multiple regression model with the variables with $p<0.20$ in $m b 1, m b 2, m b 3$, and $m b 4$ was adjusted to obtain an adjusted model per superior blocks, in which blocks 1, 2, and 3 were superior to block 4 . This last model was considered the final

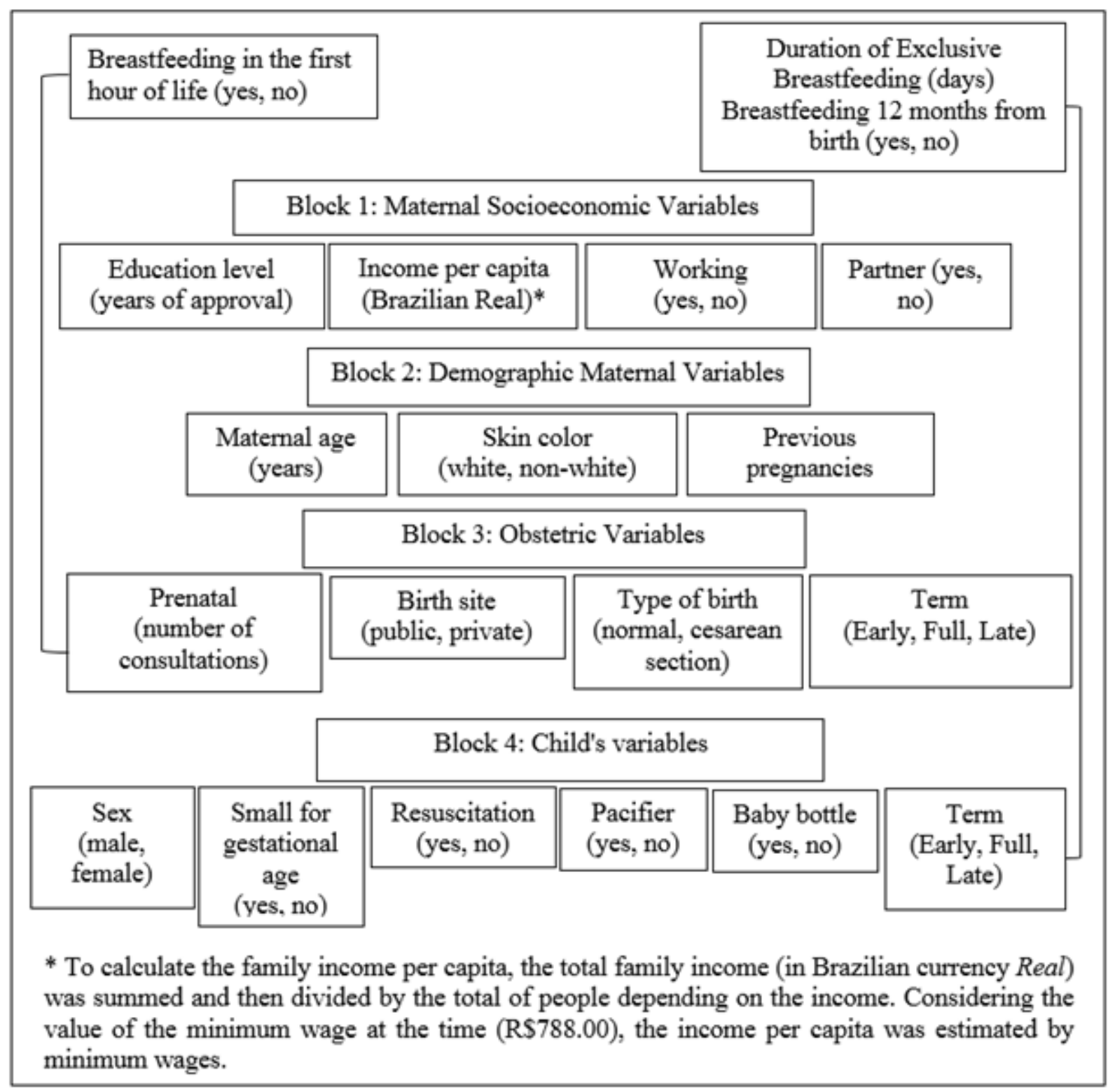

Figure 1 - Model of analysis of the three outcomes related to breastfeeding. 
model and the conclusions were extracted from its estimates. Thus, $m b 1, m b 2, m b 3$, and $m b 4$ composed the phase named internal adjustment to the blocks, performed iteratively with adjustment per superior blocks.

For the analysis relative to breastfeeding in the first hour of life, the first three blocks were used and, for EBF and BF, the four blocks were used. In all analysis, critical $\mathrm{p}<0.05$ was considered.

\section{Ethical Aspects}

The CLab study ( $\mathrm{n}^{\circ} 893.396 / 2015$ ) and this section were analyzed and approved by the Research Ethics Committee of Faculdade de Medicina de Botucatu on Opinion 2.048.392/17 and followed all presuppositions of Resolution n. 466 of the National Health Council, dated December 12, 2012.

\section{RESULTS}

Table 1 presents the personal characteristics of 608 mother-baby pairs.

The mothers whose babies were born at early term had a significantly lower education, higher income and age, had a lower number of prenatal consultations and progressed to cesarean section more frequently and in private services. Those born at early term had lower weight at birth and were breastfed less frequently in the first hour of life $(p<0.001)$ (Table 1).

Table 2 refers to breastfeeding in the first hour of life.

There was no difference in the risk of the child not being breastfed in the first hour of life according to gestational age at term. Independently, with each additional year of education $(p=0.017)$ and in the mother's age $(p=0.030)$, being born at a private service $(p=0.004)$ or by cesarean section $(p<0.001)$ and being resuscitated at birth $(p=0.015)$ increased the risk of not being breastfed in the first hour of life. Having a previous pregnancy has decreased the risk of not breastfeeding in the first hour of life $(p=0.041)$ (Table 2).

Table 3 refers to the duration of EBF.

There was no difference in the duration of EBF as per gestational age at term. Independently, mothers with no partner $(p=0.021)$ or with remunerated work $(p=0.009)$ and children using baby bottle $(p<0.001)$ interrupted EBF more quickly (Table 3 ).

Table 4 is related to the practice of BF when the child is twelve months old.

There was no difference in the practice of BF 12 years from birth according to gestational age at term. Independently, the variables use of pacifier $(p<0.001)$ or baby bottle $(p<0.001)$ have increased the risk of a child not being breastfed when 12 months old (Table 4).

\section{DISCUSSION}

Contradicting the initial hypothesis, there was no independent association between the different categories gestational age of birth at term and outcomes related to breastfeeding. Considering the variable breastfeeding in the first hour of life, the percentage difference of breastfed infants in the delivery room, $20 \%$ lower in those born at early term when compared to late term, did not result in a major risk of the newborn not being breastfed in the first hour of life when the results were adjusted for socioeconomic, demographic,

Table 1 - Characteristics of mothers and newborns participating in the study- Botucatu, SP, Brazil, 2015-2017.

\begin{tabular}{|c|c|c|c|c|}
\hline Characteristics & $\begin{array}{c}\text { Early term } \\
\text { Md(min-max)* }\end{array}$ & $\begin{array}{c}\text { Full term } \\
\text { Md(min-max)* }\end{array}$ & $\begin{array}{c}\text { Late term } \\
\operatorname{Md(min-max)*}\end{array}$ & $\mathbf{p}$ \\
\hline Education (years) & 11(1-18)a & $11(1-23) b$ & $11(2-21) b$ & $<0.001 * *$ \\
\hline Income per capita (minimum wages) & $0.8(0-10.5) a$ & $0.6(0-8.4) b$ & $0.6(0-4.2) b$ & $<0.001^{* *}$ \\
\hline Mother age (years) & 28(15-42)a & $27(14-42) a b$ & $25(16-39) b$ & $0.038^{* *}$ \\
\hline Previous pregnancies & $1(0-6)$ & $1(0-7)$ & $1(0-5)$ & $0.687^{* *}$ \\
\hline Pre-natal consultations & $8(1-15) a$ & $9(1-17) b$ & $11(1-15) \mathrm{C}$ & $<0.001^{* *}$ \\
\hline Weight at birth (grams) & $\begin{array}{c}3095 \\
(1990-4295) a\end{array}$ & $\begin{array}{c}3280 \\
(2020-4700) b\end{array}$ & $\begin{array}{c}3480 \\
(2285-4725) \mathrm{C}\end{array}$ & $<0.001^{* *}$ \\
\hline \multirow[t]{2}{*}{ Exclusive breastfeeding (days) } & $70(1-180)$ & $90(1-180)$ & $65(1-180)$ & $0.540^{* *}$ \\
\hline & n (\%) & n (\%) & n (\%) & \\
\hline Mother works & $157(62.8)$ & $150(53.4)$ & $42(54.5)$ & $0.065^{* * *}$ \\
\hline With partner & 219(87.6) & $246(87.5)$ & $67(87.0)$ & $0.953 * * *$ \\
\hline White skin color & $164(65.6)$ & $169(60.1)$ & $44(57.1)$ & $0.226^{* * *}$ \\
\hline Cesarean section & 159(63.6)a & $119(42.3) b$ & $34(44.2) b$ & $<0.001^{* * *}$ \\
\hline Childbirth at private service & 138(55.2)a & $58(20.6) b$ & $2(2.6) \mathrm{C}$ & $<0.001^{* * *}$ \\
\hline Female & 98(39.2) & $135(48.0)$ & $36(46.8)$ & $0.110^{* * *}$ \\
\hline Resuscitation at birth & $11(4.4)$ & $22(7.8)$ & $5(6.5)$ & $0.261^{* * *}$ \\
\hline Use of pacifier & $180(72.0)$ & 193(68.7) & $52(67.5)$ & $0.629 * * *$ \\
\hline Use of baby bottle & $178(71.2)$ & 192(68.3) & $52(67.5)$ & $0.719 * * *$ \\
\hline Breastfeeding in the first hour of life & 140(56.0)a & $204(72.6) b$ & $59(76.6) b$ & $<0.001^{* * *}$ \\
\hline 12-month breastfeeding & $80(32.0)$ & $105(37.4)$ & $27(35.1)$ & $0.510^{* * *}$ \\
\hline \multicolumn{5}{|c|}{$\begin{array}{l}\text { *Md(min-max): Median (minimum value-maximum value). } \\
\text { ** Kruskal-Wallis test, followed by Mann-Whitney test (multiple comparisons for numeric variables), adopting different letters to indicate statistically significant } \\
\text { differences among the categories }(p<0.05) \text {. } \\
\text { *** Chi-squared test or Fisher's Exact for categoric variables. } \\
\text { Note: early }(n=250) \text {, full }(n=281) \text {, and late }(n=77) \text { term. }\end{array}$} \\
\hline
\end{tabular}


Table 2 - Adjusted analysis to the block and per superior blocks with variables of interest and breastfeeding in the first hour of life Botucatu, SP, Brazil, 2015-2017.

\begin{tabular}{|c|c|c|c|c|c|c|}
\hline \multirow{2}{*}{ Variables } & \multicolumn{3}{|c|}{ Internal block adjustment } & \multicolumn{3}{|c|}{ Superior block adjustment } \\
\hline & $\mathrm{HR}^{*}$ & $95 \% \mathrm{Cl}^{* *}$ & $\mathbf{p}^{* * *}$ & HR $^{*}$ & $95 \% \mathrm{Cl}^{* *}$ & $\mathbf{p}^{* * *}$ \\
\hline \multicolumn{7}{|l|}{ Block 1 - Socioeconomic variables } \\
\hline Family income per capita (minimum wages) & 1.10 & $0.87-1.39$ & 0.422 & & & \\
\hline Mother's education (years) & 1.09 & $1.01-1.16$ & 0.017 & & & \\
\hline Mother works & 1.16 & $0.82-1.63$ & 0.407 & & & \\
\hline No partner & 1.03 & $0.64-1.68$ & 0.888 & & & \\
\hline \multicolumn{7}{|l|}{ Block 2 - Demographic variables + Block 1} \\
\hline Mother's education (years) & & & & 1.07 & $1.01-1.13$ & 0.230 \\
\hline Mother age (years) & 1.04 & $1.01-1.06$ & $<0.001$ & 1.03 & $1.00-1.06$ & 0.030 \\
\hline Non-white maternal color & 0.80 & $0.58-1.11$ & 0.185 & 0.85 & $0.61-1.20$ & 0.367 \\
\hline Number of previous pregnancies & 0.80 & $0.68-0.92$ & 0.003 & 0.84 & $0.72-0.99$ & 0.041 \\
\hline \multicolumn{7}{|l|}{ Block 3 - Obstetric variables + Blocks 1 and 2} \\
\hline Mother's education (years) & & & & 1.03 & $0.96-1.09$ & 0.421 \\
\hline Mother age (years) & & & & 1.01 & $0.98-1.03$ & 0.515 \\
\hline Number of previous pregnancies & & & & 0.91 & $0.78-1.06$ & 0.233 \\
\hline Number of prenatal consultations & 1.04 & $0.97-1.11$ & 0.233 & & & \\
\hline Childbirth in private service & 2.08 & $1.45-2.81$ & $<0.001$ & 1.75 & $1.20-2.56$ & 0.004 \\
\hline Cesarean section & 1.97 & $1.31-2.94$ & $<0.001$ & 2.00 & $1.33-2.99$ & $<0.001$ \\
\hline \multicolumn{7}{|l|}{ Block 4 - Child's variables + Blocks 1 to 3} \\
\hline Mother's education (years) & & & & 1.02 & $0.96-1.09$ & 0.460 \\
\hline Mother age (years) & & & & 1.01 & $0.98-1.04$ & 0.497 \\
\hline Number of previous pregnancies & & & & 0.91 & $0.77-1.06$ & 0.226 \\
\hline Childbirth in private service & & & & 1.85 & $1.19-2.86$ & 0.006 \\
\hline Cesarean section & & & & 1.87 & $1.24-2.82$ & 0.003 \\
\hline Female & 0.89 & $0.66-1.21$ & 0.474 & & & \\
\hline Small for gestational age & 0.94 & $0.64-1.37$ & 0.736 & & & \\
\hline Resuscitation at birth & 1.66 & $1.03-2.68$ & 0.036 & 1.84 & $1.13-3.02$ & 0.015 \\
\hline Full term & & & & 1 & & \\
\hline Late term & 0.88 & $0.51-1.50$ & 0.640 & 1.05 & $0.61-1.82$ & 0.850 \\
\hline Early term & 1.57 & $1.14-2.16$ & 0.006 & 1.12 & $0.79-1.58$ & 0.527 \\
\hline
\end{tabular}

* HR: Hazard Risk. ** 95\% Cl: 95\% Confidence Interval. ***Cox Multiple Regression.

obstetric factors and those related to their conditions at birth. Regarding the duration of EBF and the situation of $\mathrm{BF}$ after twelve months, these were not associated to gestational age at term in the raw analyses, which was confirmed by adjusted analyses.

Thus, gestational age at term can be considered as unassociated to breastfeeding, a result which still requires confirmation or refutation by new studies examining the same question before ruling out the negative influence of early term birth on indicators of breastfeeding, in comparison with being born at full or late term. On the other hand, this study has identified factors, previously pointed out by the literature ${ }^{(6,8)}$, as capable of influencing an early onset of breastfeeding and the duration of EBF and BF.

The proportion of breastfeeding in the first hour of life $56.0 \%, 62.6 \%$, and $76.6 \%$ for those born at early, full, and late term, respectively - was more favorable than what was found in the Amigo da Criança Hospital, which considered the overall birth at term and had a $28.7 \%$ rate $^{(17)}$. That is, the results of this study are relative to a location in which the indicators for breastfeeding in the delivery room were relatively favorable. The United Nations International Children's
Emergency Fund (UNICEF) and the WHO point out that the highest rates of this practice amount to $65 \%$ in Eastern Africa and the lowest amount to $32 \%$ in Oriental Asia and in the Pacific ${ }^{(18)}$.

The explanation for the absence of independent association between gestational age at term and breastfeeding in the delivery room may be in the fact that, despite the lower gestational age, these babies were born in favorable conditions, since in this group there was proportionally less need for resuscitation at birth and fewer cases of inappropriateness between weight and gestational age at birth. It should be considered that among those born at early term, family income and mother age were higher and, also, more frequently the delivery took place in a private service, suggesting groups with better socioeconomic and demographic conditions, which may have softened the eventual negative effect of being born with less than 40 weeks of gestational age.

Independently, sociodemographic factors which are known to vary in different contexts were associated to breastfeeding in the first hour of life, when the influence of the category gestational age at birth was examined. The highest the age and the maternal education, the highest the risk 
Table 3 - Raw analysis, adjusted to the block and per superior blocks with variables of interest and duration of exclusive breastfeeding Botucatu, SP, Brazil, 2015-2017.

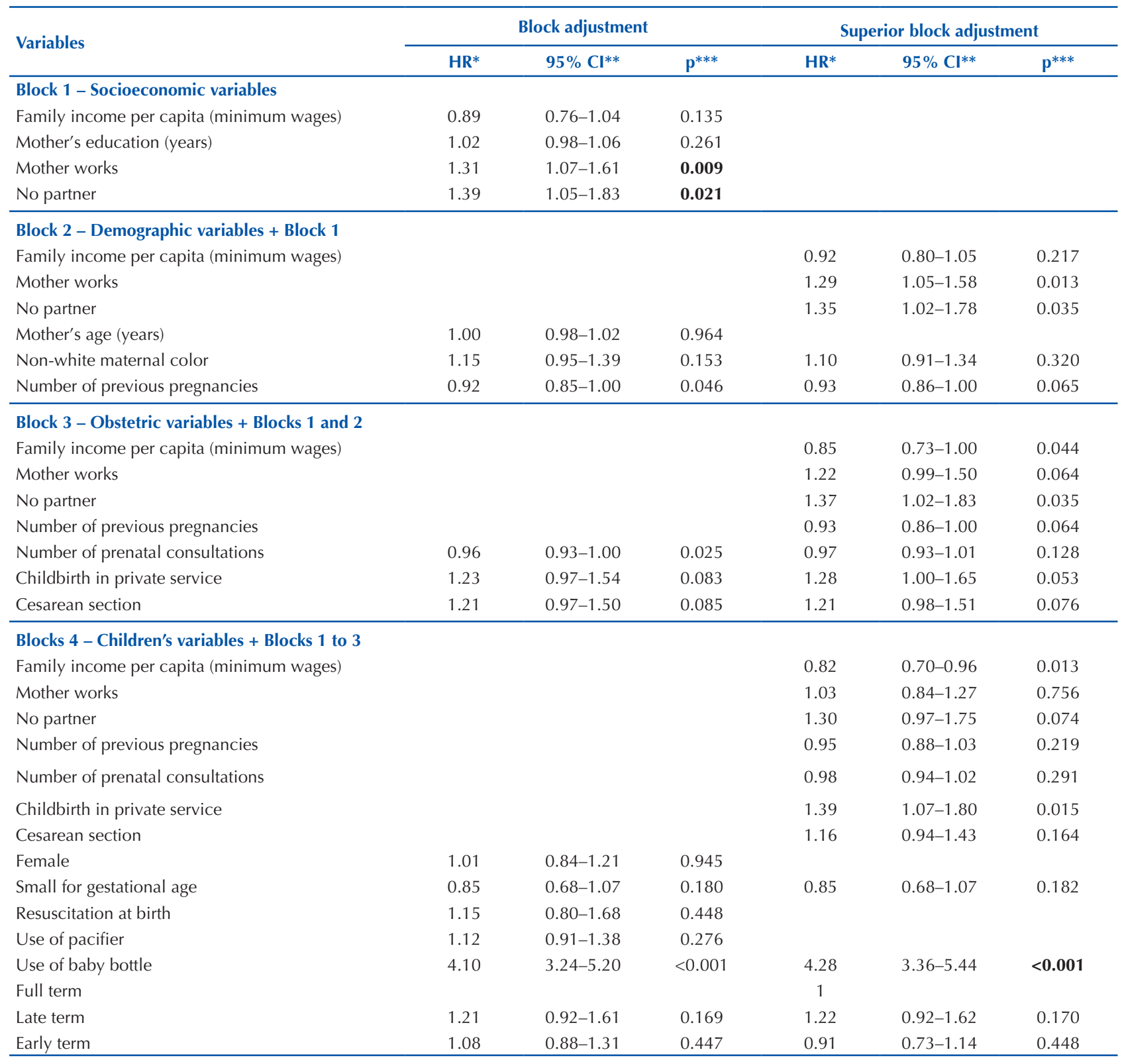

* HR: Hazard Risk. ** 95\%Cl: 95\% Confidence Interval. ***Cox Multiple Regression.

for the child not to breastfeed, whereas previous pregnancy reduces the risk of the child not breastfeeding in the first hour of life.

Regarding maternal education, in a cohort conducted in Morocco, a higher rate of breastfeeding in the first hour was identified among mothers with higher education when compared with those with primary education, respectively $78.7 \%$ vs $3.6 \%, \mathrm{p}<0.001^{(19)}$, a finding which diverges from the one obtained in this study. On the other hand, similarly, a cohort conducted in North Brazil identified a higher risk of not breastfeeding among mothers with more education: over nine years of education ${ }^{(6)}$. The mother's age was also approached by two Brazilian studies: one of them, performed in an outpatient facility specialized in breastfeeding, identified that the risk of not breastfeeding in the first hour was higher in mothers under $25^{(5)}$ and another one, conducted in an urban cluster in the Brazilian Northeast has shown that $60.2 \%$ of newborns were breastfed in the first hour of life and mother's age over 35 was a protective factor for breastfeeding ${ }^{(9)}$. A history of previous pregnancy was a protective factor for breastfeeding in the first hour of life, which differs from a finding of a meta-analysis published in 2018, which only identified an association in the continuity of breastfeeding $(\mathrm{p}<0.001)^{(20)}$.

Aligned to previous studies ${ }^{(4,5)}$, also in an independent manner, being born of cesarean section, in a private service and needing resuscitation at birth increased the risk of the child not being breastfed in the first hour of life. As a surgical 
Table 4 - Adjusted analysis to the block and per superior blocks with variables of interest and practice of breastfeeding 12 months from birth - Botucatu, SP, Brazil, 2015-2017.

\begin{tabular}{|c|c|c|c|c|c|c|}
\hline \multirow{2}{*}{ Variables } & \multicolumn{3}{|c|}{ Internal block adjustment } & \multicolumn{3}{|c|}{ Superior block adjustment } \\
\hline & $\mathbf{H R}^{*}$ & $95 \% \mathrm{Cl}^{* *}$ & $\mathbf{p}^{* * *}$ & HR $^{*}$ & $95 \% \mathrm{Cl}^{* *}$ & $\mathbf{p}^{* * *}$ \\
\hline \multicolumn{7}{|l|}{ Block 1 - Socioeconomic variables } \\
\hline Family income per capita (minimum wages) & 1.00 & $0.84-1.19$ & 0.978 & & & \\
\hline Mother's education (years) & 1.03 & $0.98-1.08$ & 0.281 & & & \\
\hline Mother works & 1.21 & $0.94-1.56$ & 0.140 & & & \\
\hline No partner & 1.03 & $0.72-1.47$ & 0.886 & & & \\
\hline \multicolumn{7}{|l|}{ Block 2 - Demographic variables + Block 1} \\
\hline Mother age (years) & 1.01 & $0.99-1.03$ & 0.333 & & & \\
\hline Non-white maternal color & 0.94 & $0.74-1.19$ & 0.605 & & & \\
\hline Number of previous pregnancies & 0.95 & $0.85-1.05$ & 0.291 & & & \\
\hline \multicolumn{7}{|l|}{ Block 3 - Obstetric variables + Blocks 1 and 2} \\
\hline Number of prenatal consultations & 0.99 & $0.95-1.04$ & 0.883 & & & \\
\hline Childbirth in private service & 1.16 & $0.88-1.53$ & 0.305 & & & \\
\hline Cesarean section & 1.09 & $0.83-1.42$ & 0.526 & & & \\
\hline \multicolumn{7}{|l|}{ Blocks 4 - Children's variables + Blocks 1 to 3} \\
\hline Mother works & & & & 1.16 & $0.92-1.48$ & 0.206 \\
\hline Female & 0.95 & $0.76-1.20$ & 0.694 & & & \\
\hline Small for gestational age & 0.91 & $0.67-1.22$ & 0.520 & & & \\
\hline Resuscitation at birth & 1.15 & $0.74-1.79$ & 0.536 & & & \\
\hline Use of pacifier & 1.67 & $1.23-2.28$ & $<0.001$ & 1.69 & $1.24-2.31$ & $<0.001$ \\
\hline Use of baby bottle & 1.95 & $1.42-2.69$ & $<0.001$ & 1.92 & $1.39-2.64$ & $<0.001$ \\
\hline Full term & & & & 1 & & \\
\hline Late term & 1.10 & $0.78-1.56$ & 0.562 & 1.11 & $0.79-1.57$ & 0.550 \\
\hline Early term & 1.07 & $0.83-1.37$ & 0.589 & 1.06 & $0.83-1.35$ & 0.654 \\
\hline
\end{tabular}

* HR: Hazard Risk. ** 95\% Cl: 95\% Confidence Interval. ***Cox Multiple Regression.

procedure, delivery through cesarean section may hinder the skin-to-skin contact within the first hour of life, a practice considered essential to promote early breastfeeding ${ }^{(21)}$. A study conducted in Pakistan verified that 53\% of women presenting difficulties with breastfeeding had been submitted to cesarean section (RR:1.38) ${ }^{(22)}$. The results obtained in the present study are in accordance with a multicenter sociodemographic study conducted in 57 low- and medium-income countries, which found the worst result for breastfeeding in the first hour of life in births occurred in the private sector and after the cesarean section ${ }^{(23)}$.

The need for resuscitation after birth is indicative of a severe clinical condition and, as such, it may preclude breastfeeding in the first minutes, hours, and even days of life. A study which sought to identify the factors for the lack of breastfeeding in the first hour of life, conducted at the Amigo da Criança Hospital, identified that, among non-breastfed babies, $67.7 \%$ presented some degree of respiratory discomfort and required maneuvers that hindered the early start of breastfeeding ${ }^{(24)}$. Thus, the obtained result, absence of association between gestational age at term and breastfeeding in the first hour of life, may have been due to infants born at early term demanding less resuscitation than those born at full term.

Considering that needing resuscitation and being born through cesarean section increased the risk of the child not being breastfed early, mother-children undergoing these procedures may be recommended to receive more attention, so that they can live this practice as fast as possible with extra support from the health team.

The duration of EBF was influenced negatively by the mother's socioeconomic conditions, such as absence of partner and work. There is evidence on the literature that the interruption of breastfeeding may be influenced by lack of incentive to mothers ${ }^{(4,25)}$, a role which might be played by the partner, and that the mother's return to work hinders the maintenance of this practice ${ }^{(26)}$.

The use of baby bottle was strongly associated to early interruption of $\mathrm{EBF}$ and the practice of $\mathrm{BF}$ twelve months from birth, a result found in the literature ${ }^{(8)}$, which is also true of the pacifier, a practice confirmed as capable of negatively influencing the situation of BF twelve months from birth. This result had already been presented by other studies on $\mathrm{BF}$ in the first two years of life $\mathrm{e}^{(8,19)}$. Considering the negative interference of using artificial nipples on EBF and $\mathrm{BF}$ and, as this is a changeable practice, actions should be implemented so as to avoid their offer.

A limitation of this study is the fact that recruitment of dyads for cohort participation was limited to a basic health unit which provides care to children in the first month of life and, thus, losses might have happened when children presented severe complications, being hospitalized for longer than one month after birth. This fact indicates that the results described here are valid for newborns in appropriate overall 
conditions. Sample size may also have been insufficient to test the associations of interest, given that it was calculated for the main objective of the CLaB study. On the other hand, data collection occurred in seven moments during the first year of life, which reduced the chance of the data on breastfeeding being influenced by memory shortcomings of the mothers, increasing their validity in relation to previous studies on BF determinants, which present, to a great extent, a cross-sectional design or data collection involving long periods of recollection.

\section{CONCLUSION}

There was no association between gestational age at term and breastfeeding in the first hour of life, duration of exclusive breastfeeding and practice of breastfeeding twelve months from birth. These results show that gestational age at term cannot by itself constitute a risk factor for outcomes related to breastfeeding. Secondarily, other risk factors have been identified for the studied outcomes.

\section{RESUMO}

Objetivo: Identificar o efeito da categoria idade gestacional no termo sobre o aleitamento materno na primeira hora de vida, a duração do aleitamento materno exclusivo e a prática do aleitamento materno aos doze meses. Método: Coorte única, com acompanhamento prospectivo de um ano de 541 crianças. Foi realizada uma análise hierarquizada, com modelos ajustados por regressão de Cox, considerando-se $\mathrm{p}$ crítico $<0,05$. Resultados: $\mathrm{Na}$ análise bruta houve diferença estatística na prática do aleitamento materno na primeira hora de vida $(R R=1,54 ; \mathrm{IC} 95 \%=1,12-2,12 ; \mathrm{p}=0,008)$. Porém, na análise final, não houve associação entre idade gestacional no termo e aleitamento materno na primeira hora de vida, duração do aleitamento materno exclusivo e prática do aleitamento materno aos doze meses. Secundariamente, encontrou-se que o aumento na idade e escolaridade, a cesárea, o nascimento em serviços privados e a necessidade de reanimação influenciaram negativamente. A vigência de gestação prévia favoreceu o aleitamento na primeira hora de vida. Usar mamadeira e chupeta foi negativo para o aleitamento no primeiro ano de vida. Conclusão: Não houve associação entre a categoria idade gestacional no termo e aleitamento materno. Confirmou-se a associação de desfechos já apontados na literatura cientifica.

\section{DESCRITORES}

Nascimento a Termo; Idade Gestacional; Aleitamento Materno; Comportamento Alimentar; Enfermagem Materno-Infantil.

\section{RESUMEN}

Objetivo: Identificar el efecto de la categoría de edad gestacional a término sobre la lactancia materna en la primera hora de vida, la duración de la lactancia materna exclusiva y la práctica de la lactancia materna a los doce meses. Método: Cohorte única, con un año de seguimiento prospectivo de 541 niños. Se realizó un análisis jerárquico, con modelos ajustados por regresión de Cox, considerando el p crítico < 0,05. Resultados: $\mathrm{El}$ análisis bruto presentó una diferencia estadística en la práctica de la lactancia materna en la primera hora de vida $(\mathrm{RR}=1,54 ; \mathrm{IC} 95 \%=1,12-2,12 ; \mathrm{p}=0,008)$. Sin embargo, en el análisis final, no hubo asociación entre la edad gestacional a término y la lactancia materna en la primera hora de vida, la duración de la lactancia materna exclusiva y la práctica de la lactancia materna a los doce meses. En segundo lugar, se encontró que el aumento de la edad y la educación, la cesárea, el nacimiento en servicios privados y la necesidad de reanimación influyeron negativamente. El embarazo previo favoreció la lactancia materna en la primera hora de vida. Usar biberón y chupete fue negativo para la lactancia en el primer año de vida. Conclusión: No hubo asociación entre la edad gestacional a término y la lactancia materna. Se confirmó la asociación de los resultados apuntados en la literatura científica.

\section{DESCRIPTORES}

Nacimiento a Término; Edad Gestacional; Lactancia Materna; Conducta Alimentaria; Enfermería Maternoinfantil.

\section{REFERENCES}

1. World Health Organisation. Guideline: protecting, promoting and supporting breastfeeding in facilities providing maternity and newborn services. Geneva: WHO; 2017.

2. Mitchell EJ, Frisbie SH, Roudeau S, Carmona A, Ortega R. Estimating daily intakes of manganese due to breast milk, infant formulas, or young child nutritional beverages in the United States and France: comparison to sufficiency and toxicity thresholds. J Trace Elem Med Biol. 2020;157:126607. doi: https://doi.org/10.1016/j.eplepsyres.2019.106192

3. Victora CG, Bahl R, Barros AJD, França GVA, Horton S, Krasevec J, et al. Breastfeeding in the 21st century: epidemiology, mechanisms, and lifelong effect. Lancet. 2016;387(10017):475-90. doi: http://dx.doi.org/10.1016/S0140-6736(15)01024-7

4. Ahmed KY, Page A, Arora A, Ogbo FA. Trends and determinants of early initiation of breastfeeding and exclusive breastfeeding in Ethiopia from 2000 to 2016. Int Breastfeed J. 2019;14:40. doi: 10.1186/s13006-019-0234-9

5. Saco MC, Coca KP, Marcacine KO, Abuchaim ÉSV, Abrão ACFV. Skin-to-skin contact followed by breastfeeding in the first hour of life: associated factors and influences on exclusive breastfeeding. Texto Contexto Enferm. 2019;28:e20180260. doi: https://doi. org/10.1590/1980-265x-tce-2018-0260

6. Ramalho AA, Martins FA, Lima TAS, Andrade AM, Koifman RJ. Fatores associados à amamentação na primeira hora de vida em Rio Branco, Acre. Demetra Aliment Nutr Saúde. 2019;14:e43809. doi: 10.12957/DEMETRA.2019.43809

7. Oliveira KA de, Araújo EM, Oliveira KA, Casotti CA, Silva CAL, Santos DB. Associação entre raça/cor da pele e parto prematuro: revisão sistemática com meta-análise. Rev Saúde Pública. 2018;52:26. doi: https://doi.org/10.11606/s1518-8787.2018052000406

8. Bezerra VM, Magalhães EIS, Pereira IN, Gomes AT, Pereira Netto M, Rocha DS. Prevalence and determinants of the use of pacifiers and feedingbottle: a study in Southwest Bahia. Rev Bras Saúde Matern Infant. 2019;19(2):311-21. doi: https://doi.org/10.1590/180693042019000200004 
9. Silva VAAL, Caminha MFC, Silva SL, Serva VMSBD, Azevedo PTACC, Batista Filho M. Maternal breastfeeding: indicators and factors associated with exclusive breastfeeding in a subnormal urban cluster assisted by the Family Health Strategy. J Pediatr. 2019;95(3):298-305. doi: http://dx.doi.org/10.1016/j.jpedp.2018.04.004

10. The American College of Obstetricians and Gynecologists. Definition of term pregnancy. Obs Gynecol. 2013;122:1139-40.

11. Tita ATN, Landon MB, Spong CY, Lai Y, Leveno KJ, Varner MW, et al. Timing of Elective Repeat Cesarean Delivery at Term and Neonatal Outcomes. N Engl J Med. 2009;360(2):111-20. doi: 10.1056/NEJMoa0803267

12. Reddy UM, Bettegowda VR, Dias T, Yamada-Kushnir T, Ko CW, Willinger M. Term pregnancy: a period of heterogeneous risk for infant mortality. Obstet Gynecol. 2011;117(6):1279-87. doi: 10.1097/AOG.0b013e3182179e28

13. American College of Obstetricians and Gynecologists. AGOG committee opinion no. 561: nonmedically indicated early-term deliveries. Obstet Gynecol. 2013;121(4):911-5. doi: 10.1097/01.AOG.0000428649.57622.a7

14. Colbourne G, Crane J, Murphy P, O'Brien D. The rates of any breastfeeding at the time of postpartum hospital discharge for early term (370-386 weeks) versus full term (390-416 weeks) infants. J Obstet Gynaecol Can. 2020;42(4):453-61. doi: 10.1016/j.jogc.2019.09.021

15. Fan HSL, Wong JYH, Fong DYT, Lok KYW, Tarrant M. Breastfeeding outcomes among early-term and full-term infants. Midwifery. 2019;71:71-6. doi: 10.1016/j.midw.2019.01.005

16. Barros AJD, Hirakata VN. Alternatives for logistic regression in cross-sectional studies: an empirical comparison of models that directly estimate the prevalence ratio. BMC Med Res Methodol. 2003;3:21. doi: 10.1186/1471-2288-3-21

17. Silva JLP, Linhares FMP, Barros AA, Souza AG, Alves DS, Andrade PON. Fatores associados ao aleitamento materno na primeira hora de vida em um hospital amigo da criança. Texto Contexto Enferm. 2018;27(4):e4190017. doi: https://doi.org/10.1590/0104-07072018004190017

18. World Health Organization. Capture the moment - early initiation of breastfeeding: the best start for every newborn. Geneva: WHO/ Unicef; 2018.

19. Habibi M, Laamiri FZ, Aguenaou H, Doukkali L, Mrabet M, Barkat A. The impact of maternal socio-demographic characteristics on breastfeeding knowledge and practices: An experience from Casablanca, Morocco. Int J Pediatr Adolesc Med. 2018;5(2):39-48. doi: https://doi.org/10.1016/j.ijpam.2018.01.003

20. Cohen SS, Alexander DD, Krebs NF, Young BE, Cabana MD, Erdmann P, et al. Factors associated with breastfeeding initiation and continuation: a meta-analysis. J Pediatr. 2018;203:190-196.e21. doi: https://doi.org/10.1016/j.jpeds.2018.08.008

21. Karimi FZ, Sadeghi R, Maleki-Saghooni N, Khadivzadeh T. The effect of mother-infant skin to skin contact on success and duration of first breastfeeding: a systematic review and meta-analysis. Taiwan J Obstet Gynecol. 2019;58(1):1-9. doi: https://doi.org/10.1016/j. tjog.2018.11.002

22. Saeed G, Fakhar S, Imran T, Laila, Abbas K. The effect of modes of delivery on infants' feeding practices. Iran J Med Sci. 2011;36(2):128-32.

23. Oakley L, Benova L, Macleod D, Lynch CA, Campbell OMR. Early breastfeeding practices: descriptive analysis of recent demographic and health surveys. Matern Child Nutr. 2018;14(2):1-9. doi: /doi/abs/10.1111/mcn.12535

24. Belo MNM, Azevedo PTÁCC, Belo MPM, Serva VMSBD, Batista Filho M, Figueiroa JN, et al. Aleitamento materno na primeira hora de vida em um Hospital Amigo da Criança: prevalência, fatores associados e razões para sua não ocorrência. Rev Bras Saúde Matern Infant. 2014;14(1):65-72. doi: https://doi.org/10.1590/S1519-38292014000100006

25. Zukova S, Krumina V, Buceniece J. Breastfeeding Preterm Born Infant: Chance and Challenge. Int J Pediatr Adolesc Med. 2020; doi: https:// doi.org/10.1016/j.ijpam.2020.02.003

26. Pac J, Bartel A, Ruhm C, Waldfogel J. Paid family leave and breastfeeding: evidence from California: Cambridge; 2019.

Financial support

Coordenação de Aperfeiçoamento de Pessoal de Nível Superior (CAPES). Código de Financiamento 01. Fundação de Amparo à Pesquisa do Estado de São Paulo (FAPESP). Processo no 2015/03256-1. 